\title{
Legitimation of Qanun in the Indonesian Law System
}

Ahyar ${ }^{1,{ }^{*}}$ Evi Djuniarti ${ }^{1}$ Muhaimin $^{1}$ Eko Noer Kristiyanto ${ }^{1}$ Ridwan Nurdin ${ }^{2}$

\author{
Ali Abubakar ${ }^{2}$
}

\author{
${ }^{1}$ Ministry of Law and Human Rights, Indonesia \\ ${ }^{2}$ Faculty of Law and Sharia-Arrani State Islamic University, Indonesia \\ *Corresponding author. Email: ahyararigayo@gmail.com
}

\begin{abstract}
The Aceh Government is given several special authority in managing its regions. One of the authorities is the application of Islamic values to local communities which are regulated based on Qanun. Qanun is a statutory regulation similar to a province/district/city regional regulation that regulates the administration of governance and the life of the Acehnese. This paper describes the status and position of qanun in the Indonesian legal system. The method used is normative juridical and empirical reinforcement through direct observation and using a qualitative approach. Legitimately the enforcement of qanun jinayat is legal because the application of the rules is by the derivation of the national law,. The implementation of Islamic law in Aceh is very much determined by the agencies and institutions related to the enforcement of qanun laws. However, it is known that the public does not know that there is a rule that applies and does not know that the regulation is in direct contact with their interests as citizens and members of society. This ignorance is due to the lack or absence of socialization or the introduction of the qanun during the midst of society.
\end{abstract}

Keywords: aceh, qanun, islamic law, government.

\section{INTRODUCTION}

With regard to social, cultural and economic plurality that exists today, there are number of national problems which include: First, National Integration which includes; inter-ethnic relations, inter-racial relations, the relationship between the center and the regions, the relationship between various development actors, social care among community members and so on. [1] Second, the Socio-Cultural Change which includes; changes in the basic orientation of cultural values, changes in traditional social systems, changes in the implementation of the legal system, social stratification, leadership patterns, advances in communication technology, impacts of tourism and so on. [2] Third, education which includes; gaps between ideal education and reality in various local and cultural situations, perceptions of education for different cultures, socio-political functions of schools as non-traditional institutions, disparities in educational progress between regions and so on. Fourth, Community Development which includes; changes in family income and expenditure, development constraints in certain areas, the rapid flow of globalization, the impact of technological advances, gaps in business opportunities, gaps in access to law, and so on. [3]

The problems mentioned above, of course, require an integrative handler with targeted instruments. Various legal products in the form of regulations and decisions must of course be able to overcome the various existing diversity. Of course, not all legal products can fulfill or satisfy all the desires of society, especially in a pluralistic society. However, if most of the aspects of life in society have been protected and recognized by the community as a limit to behavior in society, it can be said that the relevant legal product has fulfilled the sense of justice and legal certainty of the community. [4]

In the socio-cultural plurality of Indonesia, the function of law is very influential in regulating the social order. Because, basically, the law does not consider differences in ethnicity, class, position, education and so on. In addition, Indonesian National Law also comes from customary laws that apply in a region. For example, Agrarian Law comes from unwritten customary land laws. Like wise with regard to inheritance and marriage apart from customary law as well as from Islamic sharia law as currently enforced by the qanun in the Aceh region 
which is based on Islamic law. Islamic law is a series of imperative religious norms for its adherents, which obliges its people to carry out all of their religious teachings in a comprehensive, integral and comprehensive manner, in all aspects of life including the Acehnese people. [5]

The people of Aceh, also known as "Serambi Makkah", are predominantly Muslim. Based on 2010 data issued by the Central Statistics Agency (BPS), Nangroe Aceh Darussalam Province, Total Muslim population: $4,413,244$ people, Percentage: $98.19 \%$

The people of Aceh are very submissive to Islamic teachings and they obey and pay attention to the fatwas of the ulama, because it is the ulama who are the heirs of the Prophet. The appreciation of the teachings of Islam has given birth to Acehnese culture which is reflected in traditional life based on the reflections of the ulama which are then practiced, developed and preserved, then concluded as "Adat like Poteomeureuhom, law like Syiah Kuala, Qanun bak Putro Phang, Reusam like admiral" which means "Customary law is in the hands of the government and sharia law is in the hands of the Ulama". These words are a reflection of the embodiment of Islamic Shari'at in daily life practices for the people of Aceh. In other words, in the Islamic community of Aceh that is currently developing, it is customary with the Shari'a that it is impossible to separate it like compound objects that cannot be separated into two parts. [6]

Based on Law No. 11 of 2006 concerning the Government of Aceh, the Government of Aceh is given several special powers in managing its regions. One of the powers that the Aceh Government has is the application of Islamic syari'at values to the local community which are regulated based on Qanun. Qanun itself is a statutory regulation similar to a provincial / district / city regional regulation that regulates the administration of governance and the life of the Acehnese people. [7]

Islamic syari'at implemented in Aceh includes aqidah, syar'iyah and morals. Further parts of this Islamic syari'at include ahwal al-syakshiyah (family law), muamalah (civil law), jinayah (criminal law), qadha '(judiciary), tarbiyah (education), da'wah, syiar, and defense of Islam.

On 2 October 2014 the Governor of Aceh ratified the Aceh Qanun Number 6 of 2014 concerning the Law of Jinayat and the Aceh Qanun Number 8 of 2014 concerning the Principles of Islamic Sharia. This Aceh qanun has caused relatively many pros and cons in various circles, both on campus, practitioners and ordinary people. The pros and cons of a regional policy, especially with regard to the formation of sharia law materials, are natural things that need to be addressed wisely and wisely. The pros and cons of the Jinayah Law Qanun do not only appear in the regions, but also at the national and even international levels. To some extent the pros and cons have led to rejection and opposition to the implementation of the Jinayah Law Qanun in Aceh.

This paper tries to explain the implementation of qanun jinayat laws and institutions related to the implementation of Islamic law in Aceh and to explain the legitimacy of implementing qanun jinayat is related to national law.

\section{RESEARCH METHOD}

This research is an empirical legal research with a qualitative approach. , the researcher collected data that can answer two research questions, which include: firstly, an overview of the provisions stipulated in the Qanun Hukum Jinayat; and , a description of the consequences of sosilogical provisions of the Qanun Hukum Jinayat. , the researcher will collect data and information through interviews with parties related to the implementation of qanun jinayat, namely the Aceh Sharia Islamic Service, the Sharia Court, the Prosecutor's Office, the Police, the Aceh Adat Council, the Aceh People's Representative Council, the Regional Ministry Office. Aceh law, academics and Acehnese community leaders. In addition, primary legal materials are also used, namely laws and regulations relating to this research and secondary legal materials, namely books, research results, journals, scientific magazines, and newspapers.

\section{FINDING AND DISCUSSION}

The definition of Qanun itself in the Big Indonesian Dictionary is known as: Kanun, which means: laws, regulations, statutes, laws and rules. The meaning of Qanun according to the Arabic dictionary is: law, custom or custom. So it can be concluded that the meaning of Qanun is: a statutory regulation or legal rule that applies in a region (in this case in Aceh.

The term qanun has been used for a long time in the Malay language or culture. The book "Laws of Malacca" compiled in the fifteenth or sixteenth century AD has used this term. According to Liaw Yock Fang, as quoted by Al Yasa Abubakar, this term in Malay culture is used more closely with custom and is usually used when you want to distinguish between the laws stated in adat and those listed in the fiqh book. 
It is strongly suspected that the term qanun entered into Malay culture and Arabic because it began to be used in conjunction with the presence of Islam and the use of Malay Arabic in the archipelago. It is useful to mention that in Western literature this term has been used for a long time, including referring to Christian law (canon Law) which has existed since before the time of Islam.

In the Acehnese language, this term is relatively very popular and still used in the community, because one of the customary proverbs that describes the relationship between adat and syari'at is still alive In Acehnese Malay literature, qanuns have been used for a long time, and are defined as rules derived from Islamic law that have become customary. One of these manuscripts is entitled Qanun Syara 'the kingdom of Aceh which was written by Tengku di Mulek in 1257 Freehold Right by order of Sultan Alauddin Mansur Syah who died in 1870 AD This short manuscript (only a few pages) talks about several aspects of constitutional law , the division of powers of the judiciary and the authority to judge, the functions of the police and prosecutors, as well as the rules of protocol in various state ceremonies. [8]

It can be concluded that in a narrow sense, qanun is a rule that is maintained and enforced by a Sultan in his territory that is rooted in Islamic law. Whereas in a broad sense, qanun is the same as the term law or custom. it may also be stated that qanun is a term to describe the rules that apply in society which are adjustments to local conditions or further explanation of the provisions in figh established by the Sultan.

Nowadays qanun is used as a term for "regional regulations" or more precisely regional regulations which become the direct implementing regulations for laws. The enactment of the Qanun Jinayat is a criminal law unit that applies to the people of Aceh which is formed based on Islamic syari'at values. Qanun Jinayat regulates Jarimah (actions that are prohibited by Islamic law), Jarimah perpetrators, and uqubat (punishments that can be imposed by judges on perpetrators of Jarimah). One form of punishment that can be imposed on the perpetrators of Jarimah based on the Qanun Jinayat is flogging. The implementation of Islamic Sharia in Aceh is very much determined by the agencies and institutions related to the enforcement of qanun. The enforcement of Islamic law, especially the application of jinayat law in Aceh is a very important phenomenon to be observed, because from the perspective of law enforcement, this is a new initial effort in upholding Islamic law in Indonesia which has been a country that is synonymous with Positive law. [9]
Therefore, in implementing qanun jinayat and the principles of Islamic law, the aspects of the roles and responsibilities of the parties or institutions that oversee the implementation of these qanuns are very important for the achievement of the goal of creating legal certainty and of justice and security in the midst of society.

The institutions related to the implementation of Islamic Sharia law in the province of Aceh are as follows:

\section{Islamic Sharia Service}

The Islamic Sharia Service is a regional apparatus as an element implementing Islamic syari'at within the Aceh Regional Government whose position is under the Governor. This service is led by a head of service who is under and responsible to the Governor through the Regional Secretary.

The Islamic Sharia Service has the following functions: [10]

a. As executor of tasks related to planning, preparing qanuns related to the implementation of Islamic law and documenting and disseminating the results.

b. Implementation of duties related to the preparation and development of human resources related to the implementation of Islamic Shari'ah.

c. The implementation of tasks related to the smooth and orderly implementation of worship and the arrangement of its facilities as well as promoting Islamic syi'ar

d. Implementation of tasks related to guidance and supervision of the implementation of Islamic Law in the midst of society, and

e. Implementation of tasks related to the guidance and counseling of Islamic syari'at.

To carry out the functions referred to above, the Islamic Sharia Service has the authority:

a. Planning research and development programs for the elements of Islamic sharia.

b. Preserving Islamic values.

c. Develop and guide the implementation of Islamic syari'at which includes the fields of aqidah, worship, mu'amalah, morals, education and Islamic preaching, amar ma'ruf nahi munkar, baitulmal, community, Islamic syari'at, Islamic defense, qadha, jinayat, munakahat and mawaris.

d. Oversee the implementation of Islamic syari'at. 
e. Fostering and supervising the Tilawatil Qur'an Development Institute (LPTQ).

Meanwhile, according to the Central Aceh Regency Islamic Sharia Service, the researcher said that:

The main task of the Islamic Sharia Service in implementing Islamic Sharia is to carry out regional government affairs based on the principle of autonomy and duties in assisting in the field of da'wah and worship, developing Islamic Sharia resources and fostering Islamic Sharia law in accordance with statutory provisions. invitation. The functions of the Islamic Shari'at Service in implementing Islamic Shari'at are: [11]

1. The implementation of order in worship

2. Preparation of human resources for the implementation and enforcement of Islamic Shari'ah

3. Guidance and supervision of Islamic Shari'ah

4. Preparation of draft Qanuns and other legal products concerning Islamic Shari'ah and

5. Coordinate with relevant agencies in the field of implementing Islamic Shari'ah.

The authority of the Islamic Sharia Service in implementing Islamic Shari'at is;

1. Planning programs in the field of Islamic Sharia

2. Preserving Islamic values

3. Conduct research and development on the implementation of Islamic Shari'ah

4. Supervise and guide the implementation of Islamic Shari'ah

5. Cooperating with Islamic Shari'ah enforcement agencies

6. Fostering and supervising the development of the Tilawatil Qur'an (LPTQ).

Furthermore, the respondent said, some of the considerations for the formation of the Islamic Qanun Syari'at, namely;

1. Historical aspects, the habits of the predecessor society by implementing Islamic Shari'ah

2. Psychological aspects, it is integrated into the private community Juridical aspects, many laws adhered to in the past government that the king and the people were subject to the Al-Qur'an and Al-Hadith

3. Wilayatul Hisbah
Wilayatul Hisbah (hereinafter referred to as WH) is an apparatus that has the duty and obligation to oversee and control the implementation of Islamic law in Aceh. Its existence is regulated by a qanun and a governor's decree which has given full authority to this sharia enforcement apparatus to carry out the entire process of escorting fully and without hesitation.

The governor, regent / mayor and sub-district head in Aceh, like other administrative entities in Indonesia, can form Local government Police to enforce regulations related to "public order and public order." UU no. 11/2006 concerning Aceh Governance (UU PA) specifically authorizes the Aceh Regional Government to form a WH unit responsible for implementing Sharia law as part of the Satpol PP. Other Satpol PP officers occasionally conduct joint patrols and operations with their WH counterparts. [12]

All WH officers have the power to "admonish and advise, warn and provide moral guidance" to persons they suspect of violating Sharia law in Aceh, notify the appropriate authorities of possible violations of Sharia law, and facilitate the settlement of Sharia violations through procedures way or customary law. WH officers who have been appointed as Civil Servant Investigators (PPNS) have additional powers, namely to arrest and detain people accused of certain Sharia violations, for up to 24 hours and conduct police-like investigations into suspected violations. Apart from these institutions, the enforcement of sharia law also involves the police, the prosecutor's office and the Aceh Adat Council.

That the legitimacy of the Qanun is contained in the following laws and regulations: first, Law no. 18 of 2001 concerning Special Autonomy for the Province of the Special Region of Aceh as the Province of Nanggroe Aceh Darussalam. The legitimacy of the Qanun is contained in Article 1 point 8 which states that: NAD Provincial Qanun is a regional regulation as the implementation of laws in the territory of the Province of Aceh in the context of implementing special autonomy; Second, Law no. 12 of 2011 concerning the Formation of Legislative Regulations. Elucidation of Article 7 paragraph (2) a, which states that: Included in the types of provincial regulations are Qanuns that apply in Aceh and perdasus and perdasi that apply in Papua province; third, the Aceh Governance Law, Articles 21 and 22 of the Aceh Governance Law states that: Qanuns are laws and regulations similar to regional regulations governing the administration of governance and the life of the Acehnese people. [13] 
Furthermore, the provisions concerning Qanuns are contained in the Aceh Government Law, namely: 1. Aceh Qanun is: statutory regulations similar to provincial regional regulations governing the administration of governance and the life of the Acehnese people. (Article 1 number 21 of the Aceh Governance Law) 2. District / city qanuns are statutory regulations similar to district / city regional regulations governing the administration of governance and the life of district / city communities in Aceh. (Article 1 number 22 of the Aceh Governance Law)

Then in terms of the legal hierarchy in Indonesia, in accordance with the provisions of Law no. 12 of 2011 concerning the Formation of Legislative Regulations, the position of the Qanun is equalized to the Regional Regulations in other regions. According to Article 7 of Law no. 12 of 2011 concerning the Formation of Legislations, states that: the types and hierarchy of laws and regulations are as follows: the 1945 Republic of Indonesia Constitution, Law / Government Regulations in Lieu of Laws, Government Regulations, Presidential Regulations and Regional Regulations. In the explanation of Article 7 it is stated that: Included in the types of provincial regional regulations are Qanuns that apply in Aceh and Perdasus and Perdasi that apply in Papua Province. [13, pp. 75-200]

the position of the Qanun is recognized in the hierarchy of Indonesian legislation and is equated with a regional regulation. That the regulation in Law no. 12 of 2011 concerning the Formation of Legislation to facilitate the Central Government in supervising and developing regions, especially those related to the formation of a regional policy. However, attention must be paid to the specificity given by the Center to Aceh.

Furthermore, it is also related to the legitimacy of the Qanun in relation to the implementation of special autonomy for Aceh Province, it needs to be studied and explained by academics and practitioners clearly and without prejudice, so that its position and authority as mentioned above becomes clearer?

Which, , is that the Faculty of Sharia and Law in accordance with its duties and functions has a close relationship in educating experts who understand the qanuns in Aceh. In addition, socialization about the material of qanuns in the system of implementation for religious leaders and community leaders so that there is no misinformation among the community regarding the implementation of qanuns in Aceh. [14]
In addition, $t$, it is necessary to establish a kind of communication forum that involves all elements of society who routinely conduct scientific discussions and disseminate sharia qanuns in Aceh.

Through this study and explanation later, policy makers and justice seekers and even legal observers in general will easily understand that the qanun in the context of implementing special autonomy for Aceh Province can override other higher regulations, which under ordinary circumstances cannot be ruled out. by local regulations. However, as a consequence of the granting of special autonomy to the Province of Aceh, the regional legislative products may diverge from the executive products at the central level. For example, a Presidential Decree (especially with a ministerial decree) that pertains to special autonomy, the Supreme Court of course must state that this qanun applies to Aceh Province, while a Presidential Decree or Ministerial Regulation applies generally throughout Indonesia. [13, pp. 234-250]

\section{CONCLUSION}

Whereas the implementation of jinayat law as regulated by Qanun 14/2014 concerning Qanun Jinayat is carried out in order to safeguard human dignity and protect the Acehnese so that they no longer commit immoral acts against Allah. Through the implementation of qanun jinayat, the impact on the reduction of the level of violation of the Sharia among Acehnese society. To enforce qanun jinayat in Acek it is carried out by the Sharia Court, Police, Attorney General's Office, Wilayatul Hisbah (Sharia Police), Islamic Syrariat Service, Aceh Adat Council according to what is regulated in Law Number 11 of 2011 concerning Aceh Governance.

the enforcement of qanun jinayat is legal because the application of the rules is in accordance with the derivation of the national law, namely in accordance with Article 18 of the 1945 Constitution where Aceh has regional uniqueness and Law Number 44 of 1999 which is given the authority to regulate education, customs, religion and the role of ulama, as well as based on Article 125 of Law Number 11 of 2006 concerning Aceh Government, Islamic law is implemented including worship, ahhwal alsyakhshiyah (family law), muamalah (civil law), jinayah (criminal law), qadha (judiciary), tarbiyah education and preaching 


\section{REFERENCES}

[1] S. Fuady, Syariat Islam dan Politik Pasca UU RI No. 44 Tahun 1999 tentang Penyelenggaraan Keistimewaan Provinsi Nagroe Aceh Darussalam., Tangerang Selatan: YPM, 2016, pp. 25-30.

[2] R. A. M. d. Khairizzaman, Konstelasi Syariat Islam di Era Global, Banda Aceh: Dinas Syariat Islam, 2011, pp. 1-13.

[3] S. R. d. M. Kurdi, Merajut Damai Berbekal Syariat Islam, Banda Aceh: Dinas Syariat Islam, 2009, pp. 53-60.

[4] See, Qanun No. 7 tahun 2013 Tentang Hukum Acara Jinayat, 2013.

[5] The Asia Foundation, Syariat Islam Pandangan Muslim Liberal, Jakarta: The Asia Foundation, 2009.

[6] d. Syamsul Rijal, Syariat Islam dan Paradigma Kemanusian, Banda Aceh: Dinas Syariat, 2008, pp. 143-150.

[7] H. Marjono, Menegakkan Syariat Islam Dalam Konteks Ke Indonesiaan, Bandung: Mizan, 1997, pp. 27-33.

[8] Pusat Konsultasi Syariah, Penerapan Syariat Islam di Indonesia: Peluang dan Tantangan, Jakarta: Global, 2004, pp. 139-150.

[9] d. Warkum Sumitro, Hukum Islam dan Hukum Barat, Jakarta: Setara, 2017, p. 280.

[10] Al Yasa Abubakar dan Marahalaim, Hukum Pidana Islam di Nanggroe Aceh Darussalam, Banda Aceh: Dinas Syariat Islam, pp. 17-25.

[11] Hafifuddin, Peranan Ulama Dalam Pelaksanaan Syariat Islam di Aceh, (,, Lhokseumawe: MEC, 2015, p. 109.

[12] M. Zainuddin, Problematika Hukuman Cambuk di Aceh, Banda Aceh: Dinas Syariat Islam, 2011, pp. 1-7.

[13] A. Y. Abubakar, Syariat Islam di Aceh, Banda Aceh: Sahifah, 2019, pp. 23-38.

[14] Z. F. Chalil, Melihat Syariat Islam Dari Berbagai Dimensi, Banda Aceh: Dinas Syariat Islam, 2007, pp. 23-30. 